\title{
Realising Dignity in Housekeeping Work: Evidence of Five Star Hotels in Australia
}

\begin{abstract}
This article illuminates the difficulties of achieving dignity at work for hotel room attendants working at 5-star hotels in the Gold Coast region of South East Queensland, Australia. This exploratory research was founded on socialist-feminist epistemologies. In-depth interviews were conducted with a sample of 46 hotel room attendants. A qualitative, socialconstructivist, grounded-theory methodology was used to render the empirical material into a basic social structural process of achievement of dignity. Despite exploitation, marginalisation and oppression imbued in their working conditions, hotel room attendants achieve dignity through personal inclinations, dispositions, capabilities and affective domain qualities. This research has implications for hospitality industry practice.
\end{abstract}

Keywords Dignity at Work Dirty Work Hotel Room Attendants 


\section{Introduction}

Dignity, and its impact on various aspects of work, is becoming a focus of employment research (Bolton, 2010; Sabatino et al., 2014). Interest is increasing due to the fact that dignity is crucial for the well-being and the job satisfaction of employees (Sayer, 2007a), in turn influencing organisational success (Hodson \& Roscigno, 2004). Realising dignity in hotel housekeeping work reveals the basic psychological process of how room attendants harmonise the nature of their job, and associated complexities, with their 'self'. While the concept of 'self' qualities, and distinguishing between them remains controversial, some predominant elements of attitudes and behaviour were identified that were assumed by room attendants to contend with their daily trials.

Hotel room attendants work in a stigmatised dirty job, with few opportunities for career progression (Hunter Powell \& Watson, 2006). The conditions include hard physical work, intense time pressures and low pay, with a significant impact of working at the lowest level of organisational hierarchies (Onsøyen, Myukletun \& Steiro, 2009). To enable reinforcement of 'self' at the hotel workplace, room attendants who participated in this study found dignity in their employment through a suite of different masks associated with personal inclinations, dispositions, capabilities and affective domain qualities. All of these character qualities provided the hotel with some measure of making economic gains by appropriating room attendant labour as surplus value, which serves to undermine room attendants' dignity. Despite an exploitative working context, this article illuminates a basic psychological process of how room attendants resiliently found dignity in their dirty work, and serves to give 'voice' to room attendants to make known their employment experiences of working in 5-star hotels. 
However, the hotel room attendants' perception of their work contains significant contradictions. On the one hand, room attendants realise that society perceives them as being on the "lowest rung of hotels' ladder of hierarchy" (Kensbock, Jennings, Bailey, \& Patiar, 2013, p.361), acknowledging the stigma attached to their work (Hunter Powell \& Watson, 2006). On the other hand, they naturally try to construct a different positive sense of self and work dignity despite the negative perception from society of their job as dirty (Adib \& Guerrier, 2003). This poses a question that this research attempted to answer by investigating how hotel room attendants pursue work that is emotionally and physically challenging. In short, given the previous limitations of their work, the aim of this research was to provide a channel for room attendants to express an empowered voice, thus revealing how they assign a sense of dignity to their 'dirty job'.

The work of room attendants in the hotel context

In the hotel workplace, housekeeping functions are considered the largest operational department (Buchanan et al., 2010). Room attendants in this department are often referred to as chambermaids and housekeepers, highlighting the gendered characteristic of their work (Adib \& Guerrier, 2003). Given that the work of a room attendant involves ensuring the room hygiene and comfort of guests, it is stereotyped as women's work, and assumed to be an extension of women's traditional domestic household roles (Purcell, 1993). While efficiency and aptitude may be the justification for separation of work tasks, what individuals do as work greatly influences their character and well-being (Sayer, 2009). The physiological demands of room attendants' work has long been identified in hospitality literature (e.g., Boon, 2007; Hunter Powell \& Watson, 2006; Kensbock, Jennings, Bailey, \& Patiar, 2016; Knox, 2006; Liladrie, 2010; Onsøyen et al, 2009; Oxenbridge \& Moensted, 2011; Saunders \& Pullen, 1987; Sherman, 2011). The job offers few opportunities for career development, is 
associated with poor working conditions, time pressures, low job control and job insecurity (Hsieh, Apostolopoulos, \& Sonmez, 2016; Knox, Warhurst, Nickson, \& Dutton, 2015). These constraints act as obstacles for room attendants' general well-being (Crowley, 2013), hence making it subject to high staff turnover (Faulkner \& Patiar, 1997).

As employment in a particular job tends to be taken as confirming the status of those who do it (Sayer, 2007a), hotel room attendants suffer from organisational and social issues beyond the purely intense physical work (Onsøyen et al., 2009). Room attendants are front line service workers performing routine work, which is mundane, controlled and arguably low skilled (Bolton, 2007). Ashforth and Kreiner (1999) provide an analysis of the work of hotel room attendants viewing it as servile, thus reflecting a degree of social stigmatisation. Room attendants see themselves being marginalised and undervalued in the eyes of management despite the important work they provide to the hotel and guests (Hunter Powell \& Watson, 2006). Also, other employees in hotels treat them as less important workers, thus emphasising the room attendant's perceived lower worth (Kensbock et al., 2016). Not surprisingly, hotel housekeeping work is viewed as demeaning and servile by room attendants themselves (Miller \& Madsen, 2004). Many researchers characterise it as a repetitive 'dirty' job, involving tasks that are likely to be perceived as disgusting or degrading (Knox et al., 2015; Onsøyen et al., 2009). All of these working conditions serve to undermine the dignity of hotel room attendants.

Dignity involves the aspects of "integrity, respect, pride, recognition, worth and standing or status", and is eroded by "shame, stigma, humiliation, lack of recognition, or being mistrusted or taken for granted" (Sayer, 2007a, p. 565, 567). From the room attendants' point of view, their working experiences provided few positive opportunities to establish dignity, and on a daily basis their dignity was eroded through the dirty tasks they performed and the hierarchal 
operational structure of hotels in which they worked (Hunter Powell \& Watson, 2006; Miller \& Madsen, 2004).

The purpose of this study was to investigate how hotel room attendants perceive their role and commitment to work that is emotionally and physically challenging, and stigmatised by society. More specifically, given the detriments of hotel room attendants' exploitative and oppressive work, the objectives of this study were to:

1. Evaluate the ways room attendants cope with low social standing.

2. Analyze how room attendants find meaning in their 'dirty' job.

3. Describe room attendants' assignation of a sense of dignity to their job.

\section{Literature review}

The concept of 'dignity at work' is increasingly gaining attention amongst academics, researchers and managers (Bolton, 2010). Such interest is due to 'dignity' being crucial for employees' well-being and job satisfaction (Sayer, 2007a), which in turn influence organisational success (Hodson \& Rosceigno, 2004). The positive feelings associated with dignity include recognition, esteem, pride, worth and status (Sayer, 2007b). Elsewhere, researchers advocate that dignity at work should be perceived as a moral entitlement in the workplace environment (Khademi, Mohammadi \& Vanaki, 2012). In its broadest sense, dignity at work entails ensuring essential individual rights at the workplace (Hodson, 2002).

To be dignified associates with being treated as a human being in one's own right and not as merely an object or instrument (Sayer, 2007b). Dignity is something that individuals hold by virtue of their shared humanity and is directly related to one's treatment by others (Bolton, 2010; Khademi et al., 2012). Wrzesniewski, Dutton and Debebe (2003) present a model of 
interpersonal sense-making wherein the cues received from others in the course of their jobs reflect the value others ascribe to those jobs. Hence one's occupation has become a key element of esteem and pride, directly affecting dignity (Ashforth \& Kreiner, 1999).

According to Sayer (2007b), dignity can also result from others' trust and confidence and being recognised as competent. In essence, employees, regardless of their location in the hierarchal structure, want to work in a well-functioning organisation that respects their dignity and rights (Hodson, 2002). As a part of the work environment, room attendants interact on a regular basis with management, as well as other employees and guests in a servile manner, and servility has been shown to influence their dignity and self-respect (Hodson \& Rosceigno, 2004). Hodson (2002) indicates that failure to dignify employees can threaten the meaning and satisfaction achievable in their work. Lack of dignity in work leads to dissatisfaction associated with reduced motivation and job efficiency, and increased absenteeism, tension, leading to poor quality customer care (Hsieh et al., 2016; Khademi et al., 2012). Although a body of literature on dignity at work exists, there is a paucity of field research in the hotel context, particularly in relation to 'dirty work'.

\section{A Dirty Job}

A dirty job refers to work that can be physically disgusting and degrading to one's dignity (Ashforth \& Kreiner, 1999). Individuals' identity is partially based on one's occupation as a source of status and prestige (Davis, 1984). Consequently, workers in dirty jobs face challenges in building an esteem-improving identity (Ashforth \& Kreiner, 1999). Hunter Powell and Watson (2006) state that the dirty work performed by hotel room attendants portrays low status, and lack of respect and dignity. Ashforth and Kreiner (1999) argue that the common factor among dirty jobs is also based on the "visceral repugnance of people" (p. 
415), to the worker, rather than the components of the job itself. In connection with 'dirty' work, hotel room attendant work can also be classified with social taint as they appear to have a servile relationship to others (i.e., hotel guests and other staff), and they engage in the demeaning tasks of cleaning for others (Kensbock et al., 2016). Inequality conferred by servitude and inferior position, can negatively affect a worker's dignity (Sayer, 2007b). Though working in a stigmatised and tainted job, the literature indicates that those who engage in dirty work view themselves as good individuals conducting dirty jobs (Davis, 1984). Yu (2016) posits that workers cope with a stigmatised occupation by constructing positive identities for themselves by ideologically reframing social views of their job.

Achieving dignity at work is challenging in a low wage and socially stigmatised job such as room attending. This review of the literature indicates that there is little hospitality research regarding 'dignity at work'. No identified studies combine the areas of dignity at work and dirty work in relation to hotel room attendants. To fill this gap and address the three research objectives, an exploratory study was developed to evaluate hotel room attendants' perceptions of their work. The specific research questions were:

1. How do room attendants perceive their social standing?

2. What activities do they participate in that are regarded as 'dirty work'?

3. How do room attendants achieve dignity at work?

To answer the research questions and give voice to room attendants on how they find dignity through the work they perform, a socialist-feminist philosophical perspective was adopted.

\section{Methodology}

The qualitative research design involved purposive selection of participants to provide better descriptions and associations in a certain context (Savage \& Burrows, 2007). Empirical 
material was drawn from the Australian hotel industry, and only included up-market hotels identified as five-star rated, in order to encompass a broad typicality of context (Star Rating Australia, 2018). These hotels were comparable in terms of room rate and clientele to most 5star hotels in Australia and other developed countries. Ten 5-star hotels were identified and contacted in the research area of the Gold Coast in Southeast Queensland, Australia. Making initial appointments involved approval of several hierarchical levels of gatekeepers (general managers, human resource managers and executive housekeepers), with the general manager initially contacted by mail with a follow up phone call a week later to confirm participation by the hotel. Five 5-star hotels consented as potential sources of room-attendant participants, providing a potential pool of approximately 150 participants.

Room attendants were advised at a morning routine work meeting of the research purpose, and then came forward voluntarily to participate. A total of 46 hotel room attendants were interviewed, with the length of interviews averaging 30 minutes. The interviews were conducted in an empty office and participants signed an informed consent documentation. The participants ranged in age from 20 to 61 and reflect a multiplicity of ethic and cultural origins, with 25 being of Australian or European extraction. Eighteen were from a Confucian heritage and/or South East Asian background, two from Papua New Guinea and one individual from Africa.

The interview guide (Table 1) for this exploratory research followed several broad open nondirective 'grand tour' questions based on theoretical knowledge of dignity identified by Sayer (2007a), and issues identified by previous research in the context of room attendant employment experiences (See Boon, 2007; Hunter Powell \& Watson, 2006; Knox, 2006; Liladrie, 2010; Onsøyen et al, 2009; Oxenbridge \& Moensted, 2011; Saunders \& Pullen, 1987; Sherman, 2011). A qualitative grounded theory approach offered an opportunity for 
room attendants to express their opinions and feelings, revealing how they manage and make sense of their daily work. The nature of the unfolding empirical material determined the issues for further investigation. As advised by Rubin and Rubin (2005), key words and themes were explored (See Table 1), however as this was a 'grounded theory' exploratory study, the aim was to find out what the issues were from the room attendants' perspective so pre-assumption of relevant themes was not desirable. Follow-up questions were used to encourage the interviewees to expand on issues important to them, or to elicit clarification of the strategies they used to deal with particular issues, and any outcomes. These interviews were conducted in an informal atmosphere. As advocated by Small (1999), the researcherparticipant interview relationship was viewed as an interactive experience.

Table 1. Interview Guide

Room attendants were invited to comment on aspects of their employment experience using the following questions:

- Tell me how you came to be employed at this hotel?

- How would you describe your employment experience?

- What is the most challenging part of your work?

- What is the best part of your work?

- How do you feel about your work?

- Tell me about your interaction with hotel guests?

- In what ways do you feel recognised and valued for your work?

The empirical material was transcribed verbatim and subjected to analysis guided by constructivist grounded theory, which follows the original tenets described by Glaser and 
Strauss (1967) and Charmaz (2006), to provide a fully documented analytic process. Codes were developed, their properties and categories beginning with an iterative comparison of similar open codes. A second more focused (selective) layer of coding subsumed earlier material to construct categories. This focused coding was also developed by consulting the literature and it enabled examination and comparison of meanings and definitions to portray the particular contextual meanings assigned by the room attendants. The quality of this study is reflected in the trustworthiness and theoretical 'fit' that is ascribable as a consequence of member validation (confirmation of findings with participants). The following interpretation explains how hotel room attendants preserve their 'selves' and find dignity in their employment through their performance.

\section{Findings}

The implications for the room attendant 'self' and how the participating room attendants found dignity in their difficult work are now presented. The biographical data relating to the participants is detailed in Table 2 .

Table 2. Participating Room Attendants’ Biographical Information

\begin{tabular}{|c|c|}
\hline Temporal Details & Number of Participants \\
\hline Average Ages & $30-40$ years old \\
\hline Aged 20 to 29 & 9 \\
\hline Aged 30 to 39 & 14 \\
\hline Aged 40 to 49 & 13 \\
\hline Aged 50 to 59 & 1 \\
\hline Aged $60+$ & 25 years \\
\hline Participants with over 10 years' experience & 14 \\
\hline Average length of occupation experience & 6.9 years \\
\hline
\end{tabular}


Pseudonyms are used with the illustrative quotes. The identified categories included the causes of low dignity, such as working with social inequality in a dirty job, the challenges of discretion and guest perceptions of honesty. These categories are followed by having a positive attitude and taking pride in their work.

\section{Social inequality in a dirty job}

Housekeeping can be classified with social taint described as the "lowest of the low in hotel work" (Wood, 1992, p. 95), as they are at the bottom of the operational hierarchy. Room attendants are placed at the lowest level of the hotel operational and social hierarchies, recognising the public' perceptions of their low occupation classification. This stigma impacts their self-esteem, and subjective opinions of themselves. This general feeling was demonstrated by Isabella, with 13 years' experience:

We are on the end of it, the bottom rung, you feel that what we do here is not that important, even though you know that your work is key to the hotel we feel that everyone else considers us a minor detail.

Consequences of such perceptions for the room attendants were feelings of frustration at the injustice and the lack of recognition of their contribution to hotel successes. The social aversion to the task of cleaning, and the further extrapolation of the 'dirtiness' of their work, left room attendants in a position of having to avoid disclosure of their occupations when outside their workplace. Natalie, with three years' experience was fervent in her opinion of how the attitudes of others made her feel:

I hate being a room attendant, because you are looked down upon by everybody else, you feel like a piece of s..t, its degrading. 
Perceived attitudes of others resulted in feelings of self-shame. There was common use of scatological metaphors by room attendants to describe their feelings of being demeaned in their employment. One's occupation is viewed as the third most important source of identity after family and nationality (Emmison \& Western, 1990).

Room attendants realise that social views mirror their place on the lowest rung on the ladder of the hotel's hierarchy (Kensbock et al, 2016), thus acknowledging the stigma society attaches to their work (Ashforth \& Kreiner, 1999). Such examples of perceived inferior status were a source of stress for the room attendants. Many room attendants spoke of how they attempted to challenge their loss of dignity and minimise denigration of their 'self' through efforts to show their occupation was worthy. Caitlin, with four years' experience explained how she believed her own behaviour and attitude would alter the opinions of others:

If you look down on the job then other people look down on the job. But if you do your job properly and you have this high regard for your work then they will too.

Caitlin's belief in co-construction of the attitudes and values of society was a proactive measure to address others' perceptions of room attendants' low status. Moreover, hotel room attendants develop a strong attachment to their work, enabling them to reframe their low status as ennobling by providing 'comfort and care' for others (Bolton, 2005). Such levels of high moral reasoning were enacted to compensate for the lack of respect from others. Interactions with other staff and guests, reveal that inequality affected room attendants' self and role identities. Relationships with others are the base of the social fabric and context of a job (Wrzesniewski et al., 2003). Therefore, these demeaning encounters may induce detrimental psychological changes in room attendants' self-esteem (Zell \& Alicke, 2010). In this way, from a social psychological perspective (Yu, 2016), the extent of room attendants' dignity in employment was formed by their own and others' values, beliefs, perceptions and 
motives. However, their pursuit of self-respect was evident in room attendants' discretion relating to guests' personal information.

\section{Social perceptions of dirty job workers}

Key dimensions of social perceptions of a 'dirty job' accord with the themes of discretion and honesty. These themes structure the presentation of findings in the following sub-sections.

\section{Level of discretion}

Apart from the physical cleaning of guest rooms, other activities that made room attendant work 'dirty', was the assumption by management and guests that room attendants may be lacking in integrity or honesty. The room attendants' operational context demanded their integrity to ensure guests' privacy in the intimate setting of hotel bedrooms. Susan, with four years' experience, identified how these personal guest details were entrusted to her and that she relied on her own standards of responsibility:

There are issues of confidentiality and you've got to live with yourself.

The need for discretion was reported often and referred to instances involving undressed guests in intimate situations. This exposure often surprised and offended room attendants in the course of performing their tasks. Such situations are typified by Pamela, with five years' experience:

I knocked on this door several times and there was no answer so I went in and there was this guy stark naked on the bed ... [masturbating], and I was shocked, we are exposed to private lives. 
Despite adherence to protocol, the guest did not respond and Pamela entered the room. As a consequence, the room attendant was an audience to the guest's sexual act, which she found offensive. Satisfying basic sexual needs often occurred in hotel rooms and, when exposed to this activity, room attendants found these displays disconcerting. Discretion suggests room attendants draw on a suite of different masks (or 'self' presentations) to suit the situational context of their jobs. There is a requirement for diplomacy due to their exposure to guest actions in hotel rooms and discretion in assurance of guest privacy. Adopting such high moral standards enabled maintenance of self-discipline and self-reliance (Sayer, 2007a), showing room attendants were competent and trustworthy.

In addition, the hotels' standard operating procedures require room attendants to monitor guest behaviour to assist security goals by reporting potential illegal behaviour by guests and noting suspicious items in their rooms (for example firearms, large amounts of cash, or animals). Another aspect requiring discretion involved guest suicide. While suicide was not raised by most room attendants, those who broached the topic indicated how such incidents were deliberately kept quiet by hotel management. This was interpreted as a strategy to avoid negative press for the hotel. Several room attendants, did raise this aspect of discretion. Cara, with three years' experience identified the frequency of suicides in hotels:

A lot of young men do (kill) themselves in the rooms and nothing ever gets broadcast, it's like pretending it never happened.

Literature states housekeeping departments would have procedures to be "followed in the event of a death in a room" (Baker \& Huyton, 2001, p. 111). The room attendants, who mentioned guest suicide, did not report any procedures, or services such as counselling, for employees encountering these situations. In this case, the hotel's image may be prioritised over public communication or counselling for staff. 


\section{Honesty}

During cleaning and servicing rooms, room attendants recognised their particular responsibilities with regard to the issue of security and having direct access to the guests' rooms and their personal property. Room attendants viewed honesty as an important quality in their performance to ensure respect for guest's property and their employer. Angela, with 11 years' experience, conveyed her obligations to the hotelstated:

An important part of my work is to accomplish my obligation for the day. I believe in putting in an honest days' work, and you need to feel good about your effort for the day.

This commitment and dedication involved fulfilment of onerous tasks and meeting desired standards. This work orientation was further associated with taking responsibility for keeping guests' property safe in their absence. This safekeeping was expressed by room attendants as associating with feelings of being involved in personalised service and trust. Catherine, with 13 years' experience, provided an example of what she thought was important in her conduct: Like finding lost property in a room and being honest.

Recognition of her trustworthiness and reliability reinforced Catherine's self-worth in her employment. As noted by Boon (2007, p.172), “the guest's belongings operate as a proxy for the guest him/her self and must be treated with due care in the absence of the owner". Conversely, this 'honesty' category also revealed that room attendants felt their honesty was questioned at times. Many room attendants reported that trust from their hotel and guests appeared very thin when something went missing, as they felt they were the first suspect in such circumstance. Abbie, with 14 years' experience, shared her reflections, which illustrated 
the general frustration many room attendants expressed about management and guest perceptions of dishonesty which eroded her dignity:

Sometimes I am very disappointed, you know when the guest can't find something they think we steal it, and you don't, you just do the job. But I understand them because we are housekeeping and do go into their rooms, but I don't like that part, usually they find it under the bed or somewhere, but we don't get an apology.

The hotel room is a contested space of guest tenure. Having a high moral perspective (what is held to be good and right) (Leininger, 1995), was often expressed and many room attendants felt there was an inherent accusation when guest property was not located. There were no reports that these insinuated allegations were ever recanted. Feeling they were under suspicion formed a component of the room attendants' 'self'. It is believed self-perceptions are partly founded on observations of others' actions toward oneself (Jacobs, 2009). By feeling they were initial suspects of dishonesty, due to their occupation, represented discrimination for the room attendants.

\section{Dignity at work}

Despite the above mentioned cause of loss of dignity, maintaining a positive attitude and taking pride in their work was how room attendants coped with perceived assaults on their integrity and dignity. These two themes are presented in the following sub-sections.

\section{Adopting a positive attitude}

To answer the final research objective of how room attendants achieve dignity at work, the empirical material reveals room attendants believed that maintaining a positive attitude, and 
taking pride in their work was a way of coping with the lack of dignity in their job. Adopting a positive attitude enabled efficient functioning as Pamela, with five years' experience explained:

You are in the room and you have your own work and you have to be responsible in it.

Commitment to high performance improved room attendants' productivity. Nevertheless, maintaining a positive attitude was described as challenging due to the physicality and the monotony of the room attendants' daily tasks. Often room attendants had to assume a positive mask of their 'self' to hide their struggle to perform. Valerie, with 25 years' experience explained:

The beds are especially hard, because I am getting old, and maybe not 100 per cent all the time. As I am getting older I am very sick, and so tired.

Due to the physical challenges of their employment tasks many room attendants saw maintaining a positive attitude as necessary to avoid sinking into depression, as Louise, with 15 years' experience stated:

See I am still smiling, but you have to, or you just go down.

Room attendants' attitudes revealed a spectrum of feelings, which was reflected in their job satisfaction. Finding the work worthwhile from a personal fulfilment perspective provided job satisfaction, which literature reveals, enables high work standards and quality for customers (Zeithaml, Capezio \& Morehouse, 1993). All room attendants described the satisfaction that they found in their employment was through taking pride and conscientiously completing their tasks. 
Room attendants' reflections demonstrate personal commitment to their tasks, and viewing their work as important. Great effort was expended to achieve high standards of hygiene and quality task outcomes. Angela, with 11 years' experience, described how she adopted a personal standard:

I always do them as though I am the one coming into the room, so it needs to be good and it needs to be clean. I do a good job.

Abbie, with 14 years' experience, further epitomised the common perspective expressed by room attendants:

The cleanliness is satisfying, they gleam when you're done and you can take pride in that.

Taking pride was expressed by the assertive 'I' and indicated the importance of ensuring all room servicing quality details were correct. Hotel room attendants demonstrate their worth through their personal commitment to perform tasks continuously as efficiently as possible. Having pride in their work was the main expression of employment satisfaction and one of the few perceived positive aspects of this occupation. Ensuring things were as good as possible was reflected in self-evaluation of work standards as Fiona, with five years' experience, reflected:

Whatever you do you should take pride in it.

Room attendants' pride in their work was a motivating factor. It also provided a sense of achievement, which contributed to their affective commitment to the hotels' goals and values. This affective commitment is defined as "the relative strength of individual's emotional 
attachment to, identification with and involvement in their employing organisation" (Lee \& Peccei, 2007, p. 687). Taking pride in task outcomes was a means of personal 'self' enhancement that was not driven by altruistic motives.

Importantly, Lockyer (2005) identifies cleanliness as the top priority for hotel guests' choice of accommodation and satisfaction. Presenting a clean room was considered a method of welcoming the guest by meeting expectations of 5-star standards. One of the gauges of quality used by room attendants was guests' satisfaction, which was expressed by positive feedback in guest surveys or tips left at the end of the guests' stay. Complementing their desire to satisfy guests was room attendants' enjoyment of the actual outcomes of the task of cleaning. In self-evaluation of their work standards and responsibilities, room attendants monitored their attention to detail and ensured nothing was missed. Fiona, with five years' experience explained how she found fulfilment in being able to transform rooms within the time pressures:

The best part is when I see a really trashed room and at the end of it, it's all clean and it's like I've just gotten from this to that in like 30 minutes. There's a certain satisfaction in the work. I stand there at the door, I go 'I can fix this'. You have to take that pride in a job well done and a room that sparkles.

For room attendants, task fulfilment by meeting quality standards generated self-pride. Room attendants pride in their work contributed to guest satisfaction, which is an intangible aspect of hotel profitability, and indicates hotels' appropriation of surplus value created by room attendants. 


\section{Discussion}

A consensus has emerged that hotel room attendants' work has been labelled as dirty work, graded amongst the lowest of the hotel workforce, and holding little status and respect in the eyes of some management and hotel guests (Hunter Powell \& Watson, 2006; Kensbock et al., 2013; Oxenbridge \& Moensted, 2011). Research by Adib and Guerrier (2003), however, indicated that women in hotel work build a positive sense of their work despite the negative perception from society of their job. This research broadens understanding of this articulation through focus on providing 'voice' to hotel room attendants on how they find dignity despite the 'dirty' work they perform. The research findings confirm the dominant view of hotel room attendants' work as a socially tainted job and that they feel socially unequal (Ashforth \& Kreiner, 1999; Kensbock et al, 2016). Room attendants revealed that society's views mirror their occupational place on the 'lowest rung', thus acknowledge the stigma attached to their work. The gendered nature of the work was also an issue, in that traditional patriarchal views of cleaning as women's work (Adler \& Adler, 2004), placed less value on room attendants' labour, hence a greater surplus of value provided to the hotels.

Regarding their employment, the findings revealed a discriminatory situation for women working as room attendants. Through exploitation by physical demands, and marginalisation through their low level placement within hotel and social hierarchies. The nature of room attendant work means it lacks status, and involves an entirely servile relationship to others. In western/developed societies, individuals are believed to apportion themselves as belonging to social ranks based on their occupation (Thompson \& Smith, 2010). Social stereotypes were displayed when guests assumed all there was to the room attendant was the 'mask of submissiveness' (Goffman, 1959) the hotel hierarchy demanded. Literature confirms aspects of low status and stigma within the workplace may cause low self-esteem (Hallfrimsdottir, 
Phillips, Benoit \& Walby, 2008). The inequality felt by room attendants was based on their experiences of exclusion and marginalisation in both the workplace and socially.

Supporting these assumptions of how room attendants were stereotyped or categorised is that individual psychology is shaped by social hierarchical structures. The feelings, thoughts and behaviours of room attendants were encompassed by the premise of social psychology: "that group life is the setting inside of which individual experience takes place, and that such group life exerts a decisive influence on such experience" (Blumer, 1969, p. 102). Particularly in the workplace, and to a lesser degree in their social sphere, room attendants found respect from others was often lacking. The 'looking glass analogy’ of Cooley (1922) relates to how our perceptions of another's view of our appearance, behaviour, or standing influence the self. So self is a mental representation 'of the self to the self' in a collective construction of image that acts as a stimulus to guide action. This finding resonates with Sayer (2007a), as for room attendants, the erosion of their dignity was caused by lack of recognition and acknowledgment, by often being mistrusted and taken for granted. Resultant feelings of inequity based on perceptions of others' views of their abilities or value, reveal social judgment bias and distortion through status comparisons and non-acknowledgement.

Further, Sayer (2007b) states that self-respect is believed to greatly depend on how others treat us. Demeaning encounters, experienced by room attendants during guest and staff interactions, are believed to induce detrimental psychological changes in self-esteem (Zell \& Alicke, 2010). From a social psychological perspective, Yu (2016) indicates that immigrant workers' dignity in employment was formed by their own and others' values, beliefs, perceptions and motives. However, room attendants' pursuit of self-respect and self-worth was evident in discretion relating to guests' personal information and the operational context demanded integrity to ensure guests' privacy in the intimate setting of hotel bedrooms. 
Moreover, room attendants viewed honesty as an important quality in their performance to ensure respect for guest's property and their employer.

Despite the negative features recounted previously, room attendants achieved dignity in their employment by taking pride in their tasks, and maintaining a positive attitude about their job. This has been confirmed by Sayer (2007a) who stated: "To be dignified or have dignity is first to be in control of oneself, competently and appropriately exercising one's powers. Most obviously, then, dignity is about self-command and autonomy" (p.568). Taking pride in their work was a measure for room attendants to earn self-respect through positive self-evaluations of tasks well done, and this facilitated finding dignity in their dirty work. Positive selfevaluations are believed to occur unconsciously and continually, and are linked to maintaining a positive attitude (Zell \& Alicke, 2010). In this study, room attendants accepted the stigma linked to their job, and they used their involvement in dirty work to highlight the importance of their work. They actually justified the value of their job based on the very same judgments as to why their work may be viewed as tainted or dirty. Research by Ashforth and Kreiner (1999) and Bolton (2005) in other fields concur with these findings. Finding the work worthwhile for personal fulfilment perspective provided job satisfaction, elsewhere, a positive staff attitude has been identified as contributing to high quality service and guest satisfaction (Hur, Moon, \& Jung, 2015).

\section{Conclusion}

Exploring room attendants' employment experiences revealed commonalities and contradictions in self-construction, as room attendants often felt a sense of belonging and alienation within the hotel. The first objective of this study was to evaluate the ways room attendants cope with low occupational and hence low social standing. Room attendants 
exchanged their onerous labour for wages in an oppressive and exploitative environment. This exchange exposed room attendants to a world of personal power forces resulting in a faceted manifestation of social norms and discriminations. These room attendants had little control over the conditions of their employment and had minimal opportunity to express their beliefs and values within the functioning space of hotel housekeeping. So their identity was an outcome of the operational and social forces enacted within these five, 5-star hotels. This low social standing was a result of room attendant participation in what is considered 'dirty work'.

The second research objective, to analyze how room attendants find meaning in their 'dirty' job was predicated on the often discursive production of 'self' being constrained by the hotels' organisational structure, their tasks determined and limited their positive 'self'. Room attendants' identity involved convincing other staff and guests of their authenticity and worth as the ones who undertake dirty work. By dealing with aspects of some guests' behaviour, room attendants also show their unrecognised value to the hotel, particularly in the area of honesty. Discretion was the key to guests' privacy and was aligned with guests' expectations for room attendants to conduct themselves with honesty.

The study's objectives also sought to describe room attendants' assignation of a sense of dignity to their job. The positive constructs associated with dignity include recognition, esteem, pride, worth and status. Whilst lacking most of these constructs in their work, the participating room attendants took pride in their tasks and the outcome of their efforts, which provided them with dignity in their work. Through room attendants' personal inclinations, dispositions, capabilities and affective domain qualities, room attendants found dignity in their menial work. 
This article also revealed how room attendants found dignity in their employment by maintaining a positive attitude, and how this enabled reinforcement of a 'self' at the hotel workplace despite their lack of acknowledgement and perceptions of being undervalued. Central to the aim was providing room attendants with voice in how they achieved dignity at work. The purpose in following a socialist feminist critique was to generate change through challenge to the status quo by providing an avenue for room attendants to tell their story through their own 'voice'. The aim of this research was met in that an understanding provided by this study would assist broader social appreciation of room attendants' work as created cultural and historical constructions.

\section{Implications}

This study contributes to literature by revealing hotel room attendants' job motivation is 'pride in their work'. This allows them to perform to the highest standard to produce a quality product, also showing that tangible rewards are not necessarily the key to staff satisfaction or productivity. In line with the objective of this research to give room attendants' voice, this investigation reveals they face poorer working conditions, unpredictable treatment, and a lack of voice and power to redress control over these conditions. Hotel management has the potential to provide room attendants with the missing positive constructs associated with dignity - esteem, worth and status by ensuring equal treatment of these workers and acknowledging their work. More specifically, a less hierarchal management structure with more consultative relationships with room attendants would facilitate a fairer workplace and recognition of their rights and potential to contribute their knowledge to hotel operations. The jobs held by these room attendants are poorly paid, physically demanding, and unrewarding, therefore, the respect for their rights is of crucial importance for satisfaction, meaning and dignity in work. Hotels management should consider what does appear to improve room 
attendants' perceptions of dignity at work other than pay increases such as access to training and adequate resources to do their jobs (i.e. time, other staff to assist, or physical resources). Further, hotel management can reduce the physical stress for room attendants' by making operational changes so that no task exceeds medically identified human physical exertion limitations. For instance, the Executive Housekeepers may set a reasonable number of rooms to be cleaned based on the type of room (standard and VIP rooms) and amount of cleaning required (i.e., Check outs and roll-away beds).

\section{Limitations and Future Research}

This exploratory study was conducted in one small geographical area on a limited sample of 46 hotel room attendants working at 5-star properties. It will be important in future research to explore how other stakeholders, such as hotel managers, perceive the room attendants' dignity dimensions. Furthermore, various studies could be conducted to assess whether the findings in this research would still hold in different settings. Hotels of different star ratings including a broader sample geographically should be considered as the comparison may provide hotel managers with more profound insights.

\section{References}

Adib, A., \& Guerrier, Y. (2003). The interlocking of gender with nationality, race, ethnicity and class: The narratives of women in hotel work. Gender, Work \& Organization, $10(4), 413-432$.

Adler, P. A., \& Adler, P. (2004). Paradise laborers: Hotel work in the global economy. New York: Cornell University Press.

Ashforth, B., \& Kreiner, G. (1999). "How can you do it?” Dirty work and the challenge of constructing a positive identity. Academy of Management Review, 24(3), 413-434. 
Baker, K. \& Huyton, J. (2001). Hospitality management: An introduction. Melbourne: Hospitality Press.

Blumer, H. (1969). Symbolic interactionism: Perspective and method. New Jersey: Prentice Hall.

Bolton, S. (2005). Women's work, dirty work: The gynaecology nurse as 'other'. Gender, Work and Organization, 12(2), 169-186.

Bolton, S. (2010). Being human: Dignity of labor as the foundation for the spirit-work connection. Journal of Management, Spirituality and Religion, 7(2), 157-172.

Bolton, S. C. (2007). Dignity in and at work: why it matters. In S. C. Bolton (Ed.). Dimensions of Dignity at Work, pp. 3-18. London: Butterworth Heineman-Elsevier.

Boon, B. (2007). Working within the front of house/back-of-house boundary: Room attendants in the hotel guest room space. Journal of Management \& Organization, 13, $160-174$.

Buchanan, S., Vossenas, P., Krause, N., Moriarty, J., Frumin, E., Shimek, J., Mirer, F., Orris, P., Punnett, L. (2010). Occupational injury disparities in the US hotel industry. American Journal of Industrial Medicine, 53(2), 116-125.

Charmaz, K. (2006). Constructing grounded theory: A practical guide through qualitative analysis. California: Sage Publications.

Cooley, C. (1922). Human nature and conduct. New York: Scribners.

Crowley, M. (2013). Gender, the labor process and dignity at work. Social Forces, 91(4), 1209-1238.

Davis, D. (1984). Good people doing dirty work: A study of social isolation. Symbolic Interaction, 7(2), 233-247.

Emmison, M. \& Western, M. (1990). Social class and social identity: A comment on Marshall et al. Sociology, 24(2), 241-253. 
Faulkner, B., \& Patiar, A. (1997). Workplace induced stress among operational staff in the hotel industry. International Journal of Hospitality Management, 16(1), 99-117.

Glaser, B. \& Strauss, A. (1967). The discovery of grounded theory: Strategies for qualitative research. New York: Adline de Gruyt.

Goffman, E. (1959). The presentation of self in everyday life. New York: The Overlook Press.

Hallfrimsdottir, H., Phillips, R., Benoit, C. \& Walby, K. (2008). Sporting girls, streetwalkers, and inmates of houses of ill repute: Media narratives and the historical mutability of prostitution stigmas. Sociological Perspectives, 51(1), 119-138.

Hodson, R. (2002). Demography or respect? Work group demography versus organizational dynamics as determinants of meaning and satisfaction at work. British Journal of Sociology, 53(2), 291-317.

Hodson, R., \& Rosceigno, V. (2004). Organizational success and worker dignity: Complementary or contradictory? American Journal of Sociology, 110(3), 672-708.

Hsieh, Y., Apostolopoulos, Y., \& Sonmez, S. (2016). Work conditions and health and wellbeing of Latina hotel housekeepers. Journal of Immigrant and Minority Health, 18(3), $568-581$.

Hunter Powell, P. \& Watson, D. (2006). Service unseen: The hotel room attendant at work. International Journal of Hospitality Management, 25, 297-312.

Hur, W., Moon, T., \& Jung, Y. (2015). Customer response to employee emotional labor: The structural relationship between emotional labor, job satisfaction, and customer satisfaction. Journal of Services Marketing, 29(1), 71-80.

Jacobs, G. (2009). Influence and canonical supremacy: An analysis of how George Herbert Mead demoted Charles Horton Cooley in the sociological canon. Journal of the History of the Behavioral Sciences, 45(2), 117-144. 
Kensbock, S., Jennings, G., Bailey, J., \& Patiar, A. (2013). The lowest rung': Women room attendants' perceptions of five star hotels' operational hierarchies. International Journal of Hospitality Management, 35, 360-368.

Kensbock, S. Jennings, G. Bailey, J. \& Patiar, A. (2016). Performing: Hotel room attendants workplace experiences. Annals of Tourism Research, 56, 112.127.

Khademi, M., Mohammadi, E., \& Vanaki, Z. (2012). Nurses' experiences of violation of their dignity. Nursing Ethics, 19(3), 328-340.

Knox, A. (2006). The differential effects of regulatory reform: Evidence from the Australian luxury hotel industry. Journal of Industrial Relations, 48(4), 453-474.

Knox, A., Warhurst, C., Nickson, D., \& Dutton, E. (2015). More than a feeling: Using hotel room attendants to improve understanding of job quality. The International Journal of Human Resource Management, 26(12), 1547-1567.

Lee, H-J. \& Peccei, R. (2007). Organizational-level gender dissimilarity and employee commitment. British Journal of Industrial Relations, 45(4), 687-712.

Leininger, M. (1995). Transcultural nursing. Concepts, theories, research and practices. USA: McGraw-Hill.

Liladrie, S. (2010). 'Do not disturb/please clean room': hotel housekeepers in Greater Toronto. Race and Class, 52(1), 57-69.

Lockyer, T. (2005). The perceived importance of price as one hotel selection dimension. Tourism Management, 26, 529-537.

Miller, D., \& Madsen, S. (2004). The development of an instrument to address the negative perception of hospitality jobs: A pilot study. Journal of Human Resources in Hospitality \& Tourism, 2(2), 75-92. 
Onsøyen, L., Mykletun, R. \& Steiro, T. (2009). Silenced and invisible: The work-experience of room-attendants in Norwegian hotels. Scandinavian Journal of Hospitality and Tourism, 9(1), 81-102.

Oxenbridge, S. \& Moensted, L. (2011). The relationship between payment systems, work intensification and health and safety outcomes: A study of hotel room attendants. Policy and Practice in Health and Safety, 9(2), 7-26.

Purcell, K. (1993). Equal opportunities in the hospitality industry: Custom and credentials. International Journal of Hospitality Management, 12(2), 127-140.

Rubin, H. \& Rubin, I. (2005). Qualitative interviewing: The art of hearing data. (2nd ed.). California: Sage Publications.

Saunders, K. \& Pullen, R. (1987). An occupational study of room maids in hotels. London: Middlesex Polytechnic.

Savage, M., \& Burrows, R. (2007). The coming crisis of empirical sociology. Sociology, $41(5), 885-899$.

Sayer, A. (2007a). Dignity at Work: Broadening the Agenda. Organization, 14(4), 565-581.

Sayer, A. (2007b). Moral economy as critique. New Political Economy, 12(2), 261-270.

Sayer, A. (2009). Contributive Justice and meaningful work. Res. Publica, 15, 1-16.

Sherman, R. (2011). Beyond interaction: Customer influence on housekeeping and room service work in hotels. Work, Employment and Society, 25(1), 19-33.

Sabatino, L., Stievano, A., Rocco, G., Kallio, H., Pietila, A., \& Kangasniemi, M. (2014). The dignity of the nursing profession: A meta-synthesis of qualitative research. Nursing Ethics, 21(6), 659-672.

Small, J. (1999). Memory-work: A method for researching women's tourist experiences. Tourism Management, 20(1), 25-35.

Star Ratings Australia (2018). Retrived from https://www.starratings.com.au/ 
Thompson, P. \& Smith, C. (Eds.). Working life: Renewing labour process analysis. Basingstoke, UK: Palgrave MacMillan.

Wood, R. (1992). Hospitality industry labour trends: British and international experience. Tourism Management, 13(3), 297-304.

Wrzesniewski, A. Dutton, J. \& Debebe, G. (2003). Interpersonal sensemaking and the meaning of work. Research in Organizational Behavior, 25, 63-135.

Yu, K-H. (2016). Immigrant workers' responses to stigmatized work: Constructing dignity through moral reasoning. Journal of Industrial Relations, 58(5), 571-588.

Zeithaml, V., Capezio, P. \& Morehouse, D. (1993). Taking the mystery out of TQM. NJ: The Career Press.

Zell, E. \& Alicke, M. (2010). Comparisons over time: Temporal trajectories, social comparison, and self-evaluation. European Journal of Social Psychology, 40, 375382. 